Jenny J. Linnoila, MD,

$\mathrm{PhD}$

Matthew J. Binnicker, $\mathrm{PhD}$

Masoud Majed, MD

Christopher J. Klein, MD

Andrew McKeon, MD

Correspondence to

Dr. McKeon:

mckeon.andrew@mayo.edu

\title{
CSF herpes virus and autoantibody profiles in the evaluation of encephalitis
}

\section{OPEN}

\section{ABSTRACT}

Objective: To report the frequency of coexisting herpes viruses (herpes simplex virus 1 [HSV-1] or HSV-2, varicella zoster virus, Epstein-Barr virus [EBV], cytomegalovirus, or human herpes virus 6 $[\mathrm{HHV}-6])$ and autoantibodies in patients with encephalitis (herpes or autoimmune) in clinical laboratory service.

Methods: Three groups were evaluated for herpes viruses and antibodies: group 1-patients whose CSF was positive for a herpes virus by real-time PCR over a period of 6 months; group 2-patients whose CSF was positive for an autoimmune encephalitis-associated antibody over 5 years (e.g., NMDA receptor [NMDA-R] antibody), and the same number of controls without autoimmune/infectious disease; and group 3-incidental autoimmune parainfectious encephalitis cases encountered over 1 year.

Results: In group 1, antibodies were detected in 27 of 100 herpes PCR-positive CSF specimens (CSFs), either unclassified neural or nonneural in all but one patient with NMDA-R antibody detected after EBV infection. Antibodies were also detected in 3 of 7 CSFs submitted for repeat PCR testing (unclassified, 2; AMPA receptor, 1). In group 2, herpes viruses were detected in 1 of 77 controls (HHV-6) and 4 of 77 patients with autoimmune encephalitis (EBV, 2; HHV-6, 2); autoantibodies targeted NMDA-R in $3 / 4$ and $G_{A B A}-R$ in $1 / 4$. In group $3, N M D A-R$ antibody was detected in 7 patients post-HSV-1 encephalitis. Of the remaining 3 patients, 2 had unclassified neural antibodies detected, and one had $\mathrm{GABA}_{\mathrm{B}}-\mathrm{R}$ autoimmunity. Concomitant neoplasms were discovered in 2 patients each from groups 2 and 3 .

Conclusions: Autoantibodies and herpes virus DNA frequently coexist in encephalitic CSF. Some patients develop parainfectious autoimmunity following viral CNS infection (usually HSV-1 encephalitis). The significance of detecting herpes nucleic acids in others remains unclear. Neurol Neuroimmunol Neuroinflamm 2016;3:e245; doi: 10.1212/NXI.0000000000000245

\section{GLOSSARY}

AMPA-R $=\alpha$-amino-3-hydroxy-5-methyl-4-isoxazole propionic acid receptor; ANA = antinuclear antibody; AQP4 = aquaporin-4; CASPR2 = contactin-associated protein-like 2; $\mathbf{C B A}=$ cell-based assay; $\mathbf{C M V}=$ cytomegalovirus; $\mathbf{C S F \mathbf { s }}=\mathrm{CSF}$ specimens; DPPX = dipeptidyl-peptidase-like protein-6; EBV = Epstein-Barr virus; $\mathbf{G A B A}_{\mathbf{B}} \mathbf{R}=\gamma$-aminobutyric acid type B receptor; $\mathbf{G P C}=$ gastric parietal cell; $\mathbf{H H V - 6}$ = human herpes virus 6 ; $\mathbf{H S V}-\mathbf{1}=$ herpes simplex virus 1 ; IFA = immunofluorescence assay; IgG = immunoglobulin G; LDT = laboratory developed test; LGI-1 = leucine-rich glioma-inactivated 1 protein; $\mathbf{m G l u R}=$ metabotropic glutamate receptor; NMDA-R $=$ NMDA receptor; $\mathbf{S M A}=$ smooth muscle antibody; VZV = varicella zoster virus.

Neurologic autoimmunity may be triggered by cancer (paraneoplastic), infection (parainfectious), or it may be cryptogenic. ${ }^{1}$ Clinical disorders for which experimental models have been developed include anti-Yo autoimmunity, in women with cerebellar degeneration and breast or gynecologic adenocarcinoma, and ganglioside autoimmunity, in patients with Guillain-Barré syndrome arising after Campylobacter infection., ${ }^{2,3}$

Ovarian teratoma is a frequent accompaniment of paraneoplastic autoimmune encephalitis targeting the GluN1 subunit of the NMDA receptor (NMDA-R). ${ }^{4,5}$ Recent studies revealed

From the Departments of Neurology (J.J.L., C.J.K., A.M.), and Laboratory Medicine and Pathology (M.J.B., M.M., C.J.K., A.M.), College of Medicine, Mayo Clinic, Rochester, MN

Funding information and disclosures are provided at the end of the article. Go to Neurology.org/nn for full disclosure forms. The Article Processing Charge was paid by the authors.

This is an open access article distributed under the terms of the Creative Commons Attribution-NonCommercial-NoDerivatives License 4.0 (CC BY-NC-ND), which permits downloading and sharing the work provided it is properly cited. The work cannot be changed in any way or used commercially. 
that NMDA-R antibodies frequently coexist in patients with herpes simplex virus 1 (HSV-1) encephalitis, and that some antiNMDA-R encephalitis cases develop as a parainfectious autoimmune phenomenon, within weeks of HSV-1 encephalitis. ${ }^{6-11}$ Those studies confirmed suspicions that early relapse in HSV encephalitis, most notably in children, could be autoimmune. ${ }^{12}$ Typically, a striking biphasic illness occurs, whereby initial remission from viral encephalitis is followed by relapse with autoimmune encephalitis within 1 to 7 weeks of the initial presentation. ${ }^{7-11}$

Other viruses from the Herpesviridae family may trigger neurologic autoimmunity, and the spectrum of antibodies encountered may extend beyond the NMDA-R.7,13 In this study, we undertook a broad evaluation of CSF specimens (CSFs) clinically referred for either herpes or autoimmune testing in order to assess the following: (1) the frequency of neural and nonneural antibodies in CSFs from patients with herpes virus PCR positivity (identified over 6 months), (2) the frequency of herpes viruses in stored CSFs from patients with autoimmune encephalitis (identified over 5 years) and controls without inflammatory or infectious neurologic disorders, and (3) incidental cases of autoimmune encephalitis in which a parainfectious cause was considered (encountered in the Mayo Clinic Neuroimmunology Laboratory over 1 year).

METHODS Standard protocol approvals, registrations, and patient consents. The Mayo Clinic institutional review board (14-008716) approved this study. The figure demonstrates an outline of the patients.

Group 1: Autoantibody testing in CSFs with herpes PCR positivity. Residual CSFs from 100 patients evaluated in the Mayo Clinic Virology Laboratory between January 1, 2015, and June 30, 2015, that tested positive by real-time PCR for a herpes virus (HSV-1 and -2 , varicella zoster virus [VZV], Epstein-Barr virus [EBV], cytomegalovirus [CMV], and human herpes virus 6 [HHV-6]), were prospectively collected and tested for immunoglobulin $\mathrm{G}$ ( $\operatorname{IgG}$ ) antibodies by indirect immunofluorescence assays (IFAs).

Patients in whom at least $500 \mu \mathrm{L}$ of residual CSF was available on completion of virology testing were included. CSFs were refrigerated at $4^{\circ} \mathrm{C}$ and tested in the Neuroimmunology Laboratory within 5 days. Ninety-two of the $100 \mathrm{CSF}$ s were referred from practitioners outside of Mayo Clinic; 8 were internally referred. Serum was not available for testing. Of 10 CSFs subsequently submitted from the same patients for repeat virology testing within the 6-month timeframe, 7 had sufficient residual volume for neural antibody testing. Clinical histories were obtained for patients in whom well-characterized synaptic plasma membrane protein-directed antibodies (such as NMDA-R) were detected and for those with antibody detected upon repeat testing.

The IgG-class antibody assays were all interpreted by experienced observers. The assays were indirect IFAs, which consisted of the following: (1) a tissue-based assay utilizing a composite substrate of mouse brain, kidney, and intestinal tissues to identify neural antibodies (either well-characterized, such as NMDA-R, or unclassified) and nonneural antibodies (such as antinuclear antibody [ANA], smooth muscle antibody [SMA] and gastric parietal cell [GPC] antibody) by established diagnostic criteria ${ }^{14,15}$; and (2) cell-based assays (CBAs) for encephalitis-associated neural antibodies targeting cell surface synaptic antigens ( $\alpha$-amino-3-hydroxy-5-methyl-4-isoxazole propionic acid receptor [AMPA-R], aquaporin-4 [AQP4], contactinassociated protein-like 2 [CASPR2], dipeptidyl-peptidase-like protein-6 [DPPX], $\gamma$-aminobutyric acid type $B$ receptor $\left[\mathrm{GABA}_{\mathrm{B}}-\right.$ $\mathrm{R}$, metabotropic glutamate receptor 1 or 5 [mGluR1, mGluR5], leucine-rich glioma-inactivated 1 protein [LGI-1], or GluN1 subunit of the NMDA-R). For each CBA, HEK293 cells were transfected with the relevant complementary DNA and control cells were transfected with empty vector (EUROIMMUN, Luebeck, Germany). ${ }^{16}$

Five tests were performed in total on CSF at a dilution of 1:2 -1 tissue IFA, 3 composite CBAs, and 1 CBA to test for AQP4 antibody only. The composite CBAs contained chips expressing the following antigens: (1) NMDA-R, AMPA-R, and GABA $_{B}-\mathrm{R}$; (2) LGI-1 and CASPR2; (3) mGluR1, mGluR5, and DPPX. Insufficient quantity existed to determine titers. Twenty of 100 CSFs had insufficient quantity available for complete antibody testing. One test was lacking in 13 specimens, 2 tests in 6 , and 3 tests in 1; 5 total CSFs were lacking tissue IFA.

Group 2: Herpes virus testing in CSFs with synaptic antibody positivity and controls. Archived and frozen CSFs (2011-2015) from 77 patients with autoimmune encephalitis and known positivity for a neural antibody in one or more of the CBAs described above and 77 controls (antibody-negative CSFs from Mayo patients [2015] without known inflammatory or infectious CNS diseases) were tested retrospectively for herpes viruses (HSV-1/2, VZV, EBV, CMV, and HHV-6) by real-time PCR. The median patient age was 25 years (range, 2-85); 55 were female. Median control age was 49 years (range, 16-86); 49 were female. Control diagnoses were cognitive disorders $(\mathrm{n}=$ 33), epilepsy $(\mathrm{n}=15)$, movement disorders $(\mathrm{n}=11)$, no neurologic diagnosis $(n=17)$, or motor neuronopathy $(n=1)$.

For herpes virus real-time PCR testing, DNA from $200 \mu \mathrm{L}$ of raw CSF was extracted on the MagNA Pure LC 2.0 (Roche Diagnostics, Indianapolis, IN) using the Total Nucleic Acid extraction protocol. Subsequently, $5 \mu \mathrm{L}$ of extracted nucleic acid was added to a LightCycler capillary (Roche) containing $15 \mu \mathrm{L}$ of master mix for one of the following: CMV (laboratory developed test $[\mathrm{LDT}]), \mathrm{EBV}$ (Roche analyte specific reagents), HHV-6 (LDT), HSV-1 and -2 (Roche analyte specific reagents), and VZV (LDT). Testing was then performed on a LightCycler 2.0 (Roche) as previously described. ${ }^{17-20}$

Group 3: Incidental cases. Case histories of patients with findings suspicious for parainfectious autoimmune encephalitis incidentally encountered by J.L. in the course of clinical laboratory service between July 2014 and June 2015 were collated. Virology findings (from CSF only) and antibodies detected (from serum and CSF) are reported.

RESULTS Antibody testing results, virus PCR results, other CSF data, and clinical information are outlined in the figure and in tables $1-4$. 
Group 1

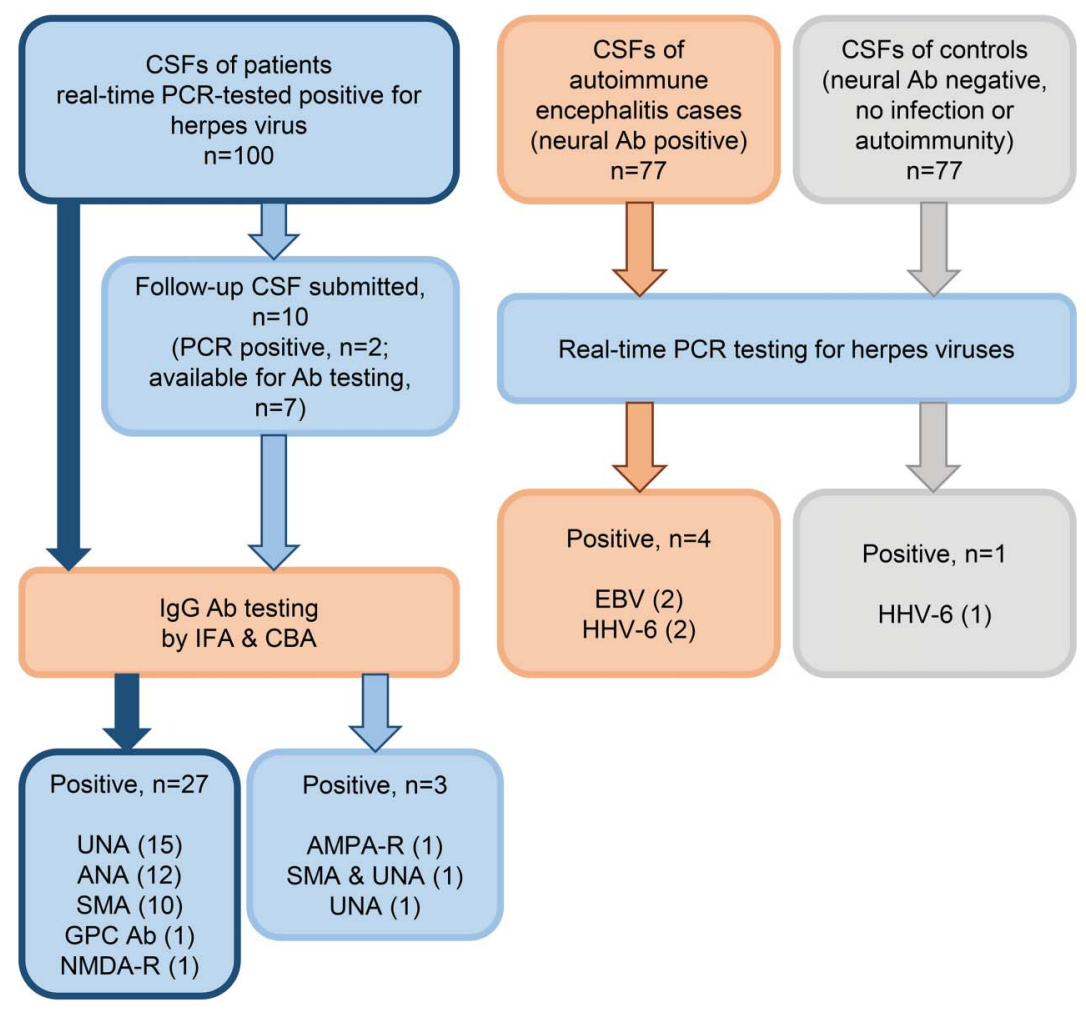

Group 3

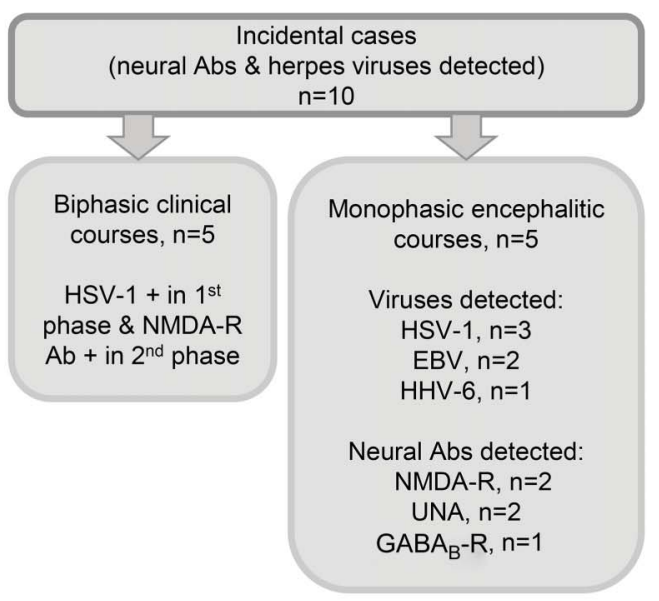

$\mathrm{Ab}=$ antibody; AMPA-R = amino-3-hydroxy-5-methyl-4-isoxazole propionic acid receptor; ANA = antinuclear antibody; CBA = cell-based assay; CSFs = CSF specimens; $\mathrm{EBV}=$ Epstein-Barr virus; $\mathrm{GABA}-\mathrm{R}=\gamma$-aminobutyric acid type $\mathrm{B}$ receptor; $\mathrm{GPC}=$ gastric parietal cell; $\mathrm{HHV}-6=$ human herpes virus 6 ; $\mathrm{HSV}=$ herpes simplex virus; IFA = immunofluorescence assay; IgG = immunoglobulin $\mathrm{G} ; \mathrm{NMDA}-\mathrm{R}=$ NMDA receptor; $\mathrm{PCR}=$ polymerase chain reaction; $\mathrm{SMA}=$ smooth muscle antibody; UNA = uncharacterized neural antibody.

Group 1: Autoantibody testing of CSFs with herpes PCR positivity. One hundred CSFs that were positive by real-time PCR for a herpes virus (one virus per specimen) were encountered over the 6-month study period. Viruses detected included HSV-2 ( $\mathrm{n}=38), \operatorname{VZV}(\mathrm{n}=30), \mathrm{HSV}-1$ ( $\mathrm{n}=18), \mathrm{EBV}$ $(n=6)$, HHV-6 $(n=6)$, and CMV $(n=2)$.
Antibodies detected in 27 of 100 CSFs by tissuebased IFA included uncharacterized neural antibodies $(\mathrm{n}=15)$, ANA $(\mathrm{n}=12)$, SMA $(\mathrm{n}=10)$, and GPC antibody $(\mathrm{n}=1)$ (table 1$)$. Only one CSF, which was EBV-positive and drawn 1 month into a meningoencephalitic illness, was antibody positive by CBA (for NMDA-R antibody). This patient was also positive

Table 1 Group 1 patient demographics, viral species detected, and tissue IFA antibody findings in CSF $(n=100)$

\begin{tabular}{|c|c|c|c|c|}
\hline $\begin{array}{l}\text { Herpes virus } \\
\text { detected in CSF }\end{array}$ & $\begin{array}{l}\text { No. positive for viral } \\
\text { nucleic acid and tested } \\
\text { for Abs (female sex) }\end{array}$ & Median age, y (range) & $\begin{array}{l}\text { No. positive for Abs } \\
\text { (\% of tested); female sex }\end{array}$ & Autoantibodies detected (No.) \\
\hline HSV-1 & $18(9)$ & $72(0.6-89)$ & $3(16) ; 2$ & SMA (1), UNA (1), GPC Ab and UNA (1) \\
\hline HSV-2 & $38(28)$ & $37(0.1-70)$ & $9(23) ; 5$ & ANA (3), ANA and UNA (3), SMA (2), UNA (1) \\
\hline VZV & 30 (12) & 79 (13-93) & $9(30) ; 5$ & ANA (3), UNA (3), SMA and UNA (2), SMA (1) \\
\hline EBV & $6(2)$ & $58(34-85)$ & $4(67) ; 1$ & $\begin{array}{l}\text { SMA, ANA, and NMDA-R (1), SMA and ANA } \\
\text { (1), UNA (1), SMA and UNA (1) }\end{array}$ \\
\hline CMV & $2(1)$ & $41(37-45)$ & $1(50) ; 0$ & SMA and UNA (1) \\
\hline HHV-6 & $6(1)$ & $54(1.5-67)$ & 1 (17); 0 & ANA and UNA (1) \\
\hline Total & $100(53)$ & $57(0.1-93)$ & 27 (27); 13 & $\begin{array}{l}\text { Total patients (27), UNA (15), ANA (12), } \\
\text { SMA (10), NMDA-R (1), GPC Ab (1) }\end{array}$ \\
\hline
\end{tabular}

Abbreviations: $\mathrm{Ab}=$ antibody; $\mathrm{ANA}=$ antinuclear $\mathrm{Ab}$; $\mathrm{CMV}=$ cytomegalovirus; $\mathrm{EBV}=$ Epstein-Barr virus; GPC = gastric parietal cell; $\mathrm{HHV}-6=$ human herpes virus $6 ; \mathrm{HSV}=$ herpes simplex virus; IFA = immunofluorescence assay; NMDA-R = NMDA receptor; $\mathrm{SMA}=$ smooth muscle Ab; UNA = unclassified neural $\mathrm{Ab}$; VZV = varicella zoster virus. 
for ANA and SMA by tissue-based IFA (tables 1 and 2) and had signs of systemic EBV infection as well as meningoencephalitis. CSF drawn 3 months after illness onset had neither antibodies nor EBV detected. The authors subsequently obtained an aliquot of CSF drawn 2 weeks into the illness from the referring provider. Viral testing was negative for EBV. Antibody testing revealed ANA alone.

Autoantibody testing of follow-up CSFs. CSFs from 10 of the 100 patients with prior herpes virus PCR positivity (including the patient with EBV infection described above, Table 2 , row 1 ) were subsequently tested by realtime PCR within a median of 7 weeks after the initial evaluation (range, 1.3-21). Two were still positive for herpes viruses, one for CMV (1.3 weeks after the first CSF test), and one for HHV-6 (3.5 weeks later). Sufficient specimen volumes were available for antibody testing in 7 of the $10 \mathrm{CSF}$ (including the 2 with repeat herpes positivity). Antibodies were detected in 3 of 7 repeat CSFs (43\%, table 2, rows 2-4). Of these patients, the first 2 described were considered to have a parainfectious autoimmune disorder by the treating physicians. The first patient with a biphasic encephalitic course had GPC antibody detected in the initial HSV-1
PCR-positive CSF, and AMPA-R antibody (but not GPC antibody) detected in CSF submitted 9 weeks later. The second patient with zoster myelitis who developed encephalopathy during recovery from myelopathy had SMA detected in the initial VZV PCR-positive CSF, and SMA and an unclassified neural antibody (but not VZV) detected in CSF submitted 3 weeks later. A third patient, with encephalopathy, recurrent lymphoma with spread to the CNS, and HHV-6 viremia, tested positive for both HHV-6 and an uncharacterized neural antibody in both CSFs submitted. The significance of the viral and antibody findings was uncertain in that patient.

Group 2: Herpes virus testing of CSFs with synaptic antibody positivity and controls. Among stored CSFs from 77 patients diagnosed with autoimmune encephalitis, the following antibodies were detected: NMDA-R $(\mathrm{n}=56), \mathrm{GABA}_{\mathrm{B}} \mathrm{R}(\mathrm{n}=13)$, LGI-1 $(\mathrm{n}=2)$, DPPX $(n=2)$, CASPR2 ( $=1)$, AMPA-R $(n=1)$, NMDA-R and AMPA-R ( $\mathrm{n}=1)$, and NMDA-R and $\mathrm{GABA}_{\mathrm{B}}-\mathrm{R}(\mathrm{n}=1)$. Four of 77 CSFs were positive by herpes virus real-time PCR: 2 for EBV (both patients had anti-NMDA-R encephalitis) and 2 for HHV-6 (one patient had anti-NMDA-R encephalitis, the other had

Table 2 Group 1 patients with serial CSF specimens in whom neural autoantibodies were detected $(n=4)$

\section{Age, y/sex/race/ interval between CSF tests, wk}

$46 / F / C / 9$

$43 / \mathrm{M} / \mathrm{C} / 3$

$63 / \mathrm{M} / \mathrm{H} / 4$

Available CSF findings

1st CSF

WCC, $600150 \%$

PMNs); protein, 228 EBV; ANA ${ }^{\mathrm{a}}$; SMA ${ }^{\mathrm{a}}$; NMDA-R $A b^{a, b}$

WCC, $486160 \%$ lymphs); protein, 429; VZV; $S M A^{a}$

WCC, 7 (87\% lymphs; $9 \%$ atypical); protein 99; HHV-6; UNA ${ }^{a}$

\section{2nd CSF}

Negative

lymphadenopathy. MRI demonstrated leptomening
enhancement. Initial CSF, not obtained by authors, demonstrated 1,100 WBCs (50:50, PMNs: lymphocytes); viral studies were negative. Subsequent worsening coincided with 1st CSF evaluated by authors. Patient had gradual clinical improvement and resolution of scan findings, partly attributable to steroid therapy. Died suddenly in her sleep 2 mo later

Severe encephalitis, requiring tracheostomy and percutaneous feeding tube. Mild improvement with antiviral treatment. Re-presented 2.5 mo later in coma after cardiac arrest. Care withdrawn; patient died

Diagnosed with zoster myelitis in setting of immunosuppression for neurosarcoidosis.

Immunosuppression was stopped to treat zoster. He developed encephalopathy, which resolved on restarting immunosuppression

lymphs); protein, 270;

$\mathrm{SMA}^{\mathrm{a}} ; \mathrm{UNA}^{\mathrm{a}}$

WCC, 34 (84\% lymphs; $13 \%$ atypical); protein 140; HHV-6; UNA
History of HTLV-associated T cell lymphoma. Remitted after chemotherapy and SCT. Developed GVHD. Presented with month of encephalopathy. Found to have CNS lymphoma. MR demonstrated diffuse leptomeningeal enhancement. Did not respond to chemotherapy. Had concomitant worsening of HHV-6 viremia. Discharged to hospice

\section{Diagnosis}

Likely systemic EBV and EBV meningoencephalitis, followed by anti-NMDA-

$R$ encephalitis followed by AMPA-R encephalitis

VZV myelitis followed by autoimmune encephalopathy

CNS lymphoma, HHV-6 viremia; possible autoimmune, HHV-6, or paraneoplastic encephalitis

Abbreviations: $\mathrm{Ab}=$ antibody; AMPA-R = amino-3-hydroxy-5-methyl-4-isoxazole propionic acid receptor; $\mathrm{ANA}=$ antinuclear $\mathrm{Ab} ; \mathrm{C}=\mathrm{Caucasian} ; \mathrm{CN}=$ cranial nerve; $\mathrm{EBV}=$ Epstein-Barr virus; GPC = gastric parietal cell; GVHD = graft vs host disease; $\mathrm{H}=\mathrm{Hispanic}$; HHV- $6=$ human herpes virus 6 ; HSV = herpes simplex virus; HTLV = human T lymphotrophic virus; lymphs = lymphocytes; NA = not available; NMDA-R = NMDA receptor; PMN $=$ polymorphonuclear white cell; SCT = stem cell transplant; $S M A=$ smooth muscle $A b ; U N A=$ unclassified neural $A b ; V Z V=$ varicella zoster virus; WBC $=$ white blood cell; WCC $=$ white cell count.

Normal CSF values: protein, $\leq 35 \mathrm{mg} / \mathrm{dL} ; \mathrm{WCC}, \leq 5 / \mu \mathrm{L}$.

${ }^{a}$ Detected by tissue-based immunofluorescence assay.

${ }^{b}$ Detected by cell-based immunofluorescence assay.

${ }^{\mathrm{c}}$ HSV-1 not retested. 
Table 3 Group 2 patients with diagnoses of autoimmune encephalitis in whom herpes viruses were detected $(n=4)$

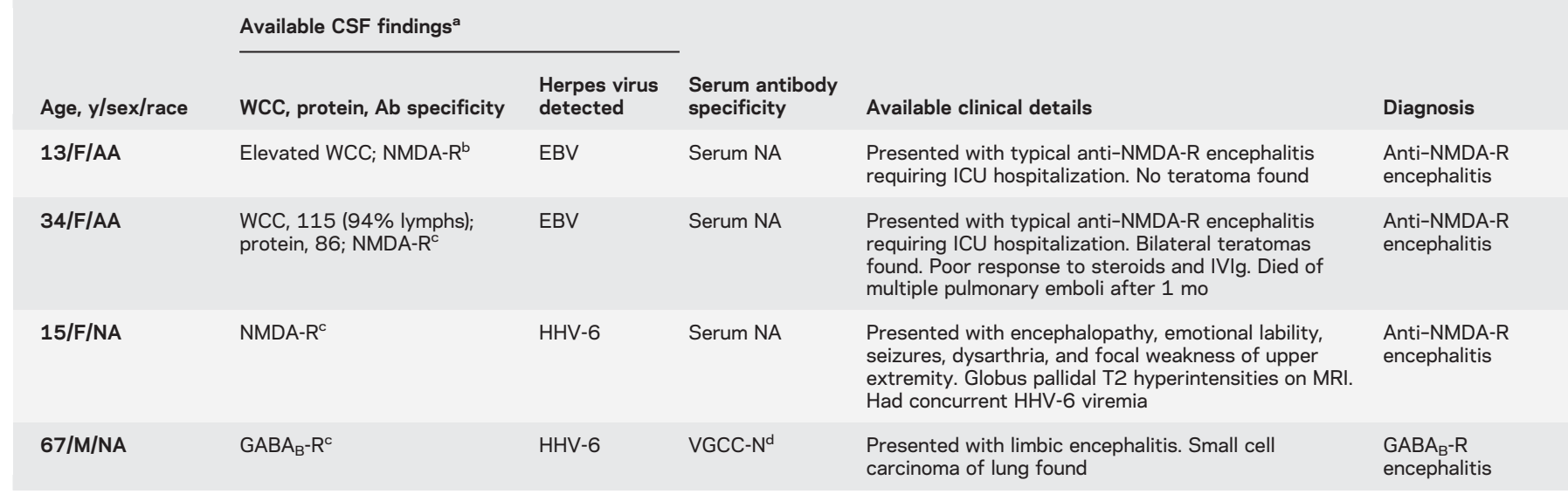

Abbreviations: $A A=$ African American; $A b=$ antibody; $E B V=$ Epstein-Barr virus; $G A B A_{B}-R=\gamma$-aminobutyric acid type $B$ receptor; HHV- $6=$ human herpes virus 6 ; ICU = intensive care unit; IVIg = IV immunoglobulin; lymphs = lymphocytes; NA = not available; NMDA-R = NMDA receptor; VGCC-N = N-type voltage-gated calcium channel; $\mathrm{WCC}=$ white cell count.

CSF normal values: protein, $\leq 35 \mathrm{mg} / \mathrm{dL} ; W C C, \leq 5 / \mu \mathrm{L}$.

${ }^{a}$ All detected in the same CSF specimen.

${ }^{\mathrm{b}}$ Detected by tissue-based immunofluorescence assay only.

${ }^{c}$ Detected by tissue-based and cell-based immunofluorescence assays.

${ }^{\mathrm{d}}$ Detected by immunoprecipitation assay.

$\mathrm{GABA}_{\mathrm{B}}-\mathrm{R}$ encephalitis [table 3]). None had a history of infectious encephalitis recorded. Two of the 4 patients also had neoplasia (bilateral ovarian teratomas and small cell lung carcinoma) detected and were diagnosed with a paraneoplastic (rather than parainfectious) encephalitis. Among 77 control CSFs (antibody negative, from patients without inflammatory or infectious CNS disease), one tested positive for HHV-6. The patient was a 21-year-old woman with chronic intractable cryptogenic focal epilepsy, without clinical, radiologic, or CSF evidence of CNS infection or autoimmunity.

Group 3: Incidental cases. In the course of clinical consultative correspondence with outside physicians over 12 months, 10 patients were encountered with CSF positivity for both herpes PCR and neural antibodies concurrently or sequentially (table 4). Eight patients had HSV-1 alone detected (3 were children), one had both EBV and HHV-6 detected, and one had EBV alone.

Five patients had biphasic clinical courses and were recognized to have a postinfectious autoimmune disorder. All had HSV-1 detected during the first phase and NMDA-R antibody detected during the second phase. Three were older than 60 years, and 2 were younger than 2 years; all were female. Initial encephalitic illnesses were followed by improvement attributed to antiviral therapy. Relapse of encephalitic symptoms occurred a median of 4 weeks later (range, 1-6). One pediatric patient developed a hyperkinetic movement disorder during the second phase. Immunotherapy data were available for 3 patients, 2 of whom improved.
Five patients had monophasic encephalitic courses. In one child, HSV-1 infection was initially suspected and was confirmed by PCR. Further evaluation was prompted by lack of improvement and development of orofacial dyskinesias despite prompt treatment with antiviral therapy. Anti-NMDA-R encephalitis was suspected and confirmed by CSF testing. A second patient had a clinical course typical for severe anti-NMDA-R encephalitis from the outset, and had both NMDA-R antibody and EBV detected in the same CSF specimen. The significance of the virology finding was unknown. Two further patients had both HSV-1 and neoplasia detected during evaluations for encephalitis. One of those 2 patients had $\mathrm{GABA}_{\mathrm{B}}-\mathrm{R}$ encephalitis and small cell lung carcinoma, and was concluded to have paraneoplastic encephalitis. The other had an unclassified neural antibody and renal cell carcinoma detected, but the cause of encephalitis (infectious, parainfectious, or paraneoplastic) was uncertain. The final patient had encephalopathy, which progressed to a minimally responsive state over the course of 1 year. Despite extensive evaluations, a cause was not determined. Both EBV and HHV-6 were detected in the initial CSF. Repeat CSF testing over the year persistently demonstrated an elevated white cell count, HHV-6 PCR positivity, and an unclassified neural antibody. There were no neurologic improvements after multiple antiviral treatments and immunotherapies.

DISCUSSION In this study based in the Mayo Clinic Virology and Neuroimmunology clinical laboratories, autoantibodies and herpes nucleic acids were commonly 
Table 4 Group 3 (incidental cases) in whom parainfectious autoimmunity was considered $(n=10)$

\section{Available CSF finding}

\begin{tabular}{|c|c|c|c|c|c|c|c|}
\hline \multirow[b]{2}{*}{$\begin{array}{l}\text { Age, yl } \\
\text { sex/race }\end{array}$} & & & & \multirow[b]{2}{*}{$\begin{array}{l}\text { Serum Abs detected } \\
\text { (wk after positive } \\
\text { herpes CSF) }\end{array}$} & \multirow[b]{2}{*}{ Clinical data } & \multirow[b]{2}{*}{ Diagnosis } & \multirow[b]{2}{*}{ Treatment, response } \\
\hline & WCC, protein, OCBs & $\begin{array}{l}\text { Herpes viruses } \\
\text { detected }\end{array}$ & $\begin{array}{l}\text { CSF Abs (wk after } \\
\text { positive herpes CSF) }\end{array}$ & & & & \\
\hline 1/F/NA & NA & $H S V-1^{a, b}$ & NMDA-R Ab, ${ }^{\mathrm{c}, \mathrm{d}}$ ANA (4) $)^{\mathrm{d}, \mathrm{e}}$ & SMA (4) & $\begin{array}{l}\text { Biphasic neurologic course; relapse with } \\
\text { chorea occurred after } 4 \mathrm{wk}\end{array}$ & $\begin{array}{l}\text { Anti-NMDA-R } \\
\text { encephalitis, post-HSV- } \\
1 \text { encephalitis }\end{array}$ & NA \\
\hline 1/F/AA & $\begin{array}{l}\text { 1st: WCC, } 21 \text { ( } 40 \% \text { PMNs); } \\
\text { 2nd: WCC, } 3 \text { (90\% lymphs); } \\
\text { protein, } 24\end{array}$ & $H S V-1^{a, b}$ & NMDA-R Ab (11) $)^{\mathrm{d}, \mathrm{f}}$ & NMDA-R $(13)^{f}$ & Severe biphasic neurologic course & $\begin{array}{l}\text { Anti-NMDA-R } \\
\text { encephalitis, post-HSV- } \\
1 \text { encephalitis }\end{array}$ & $\begin{array}{l}\text { No improvement after IVMP and IVIg. } \\
\text { Persistent seizures and developmental } \\
\text { delay }\end{array}$ \\
\hline $61 / \mathrm{F} / \mathrm{NA}$ & NA & $H S V-1^{a}$ & $\begin{array}{l}\text { UNA, a,d,f NMDA-R Ab } \\
(6)^{c, d}\end{array}$ & Negative (0) & $\begin{array}{l}\text { Biphasic clinical course. Relapse } \\
\text { occurred after } 6 \mathrm{wk}\end{array}$ & $\begin{array}{l}\text { Anti-NMDA-R } \\
\text { encephalitis, post-HSV- } \\
1 \text { encephalitis }\end{array}$ & NA \\
\hline 63/F/C & $\begin{array}{l}\text { 1st: WCC, 14; protein, 60; } \\
\text { 2nd: WCC, } 79 \text { ( } 76 \% \text { lymphs); } \\
\text { protein } 79 ; \text { OCBs, } 15\end{array}$ & HSV-1 $1^{a, b}$ & $\begin{array}{l}\text { NMDA-R Ab, }{ }^{c, d} \text { ANA, }{ }^{d, e} \\
\text { SMA (4) })^{d, e}\end{array}$ & Negative (4) & $\begin{array}{l}\text { Biphasic neurologic course. Relapse } \\
\text { after } 3 \mathrm{wk}\end{array}$ & $\begin{array}{l}\text { Anti-NMDA-R } \\
\text { encephalitis, post-HSV- } \\
1 \text { encephalitis }\end{array}$ & $\begin{array}{l}\text { 1st event: improved with antiviral } \\
\text { therapy; } 2 \text { nd event: improved with IVMP } \\
\times 5 \text {, still severe cognitive dysfunction }\end{array}$ \\
\hline 67/F/C & $\begin{array}{l}\text { 1st: WCC, } 730 \text { (95\% lymphs); } \\
\text { 2nd: WCC, } 10 \text { (90\% lymphs) }\end{array}$ & $H S V-1^{a, b}$ & $\begin{array}{l}\text { NMDA-R Ab, }{ }^{c, d} \text { ANA, }{ }^{d, e} \\
\text { SMA }(6)^{d, e}\end{array}$ & Negative (6) & $\begin{array}{l}\text { Biphasic neurologic course. Relapse } \\
\text { after } 6 \text { wk }\end{array}$ & $\begin{array}{l}\text { Anti-NMDA-R } \\
\text { encephalitis, post-HSV- } \\
1 \text { encephalitis }\end{array}$ & $\begin{array}{l}\text { 1st event: improved with antiviral } \\
\text { therapy; } 2 \text { nd event: normalized with } \\
\text { IVIg, rituximab, and cyclophosphamide } \\
\text { after long recovery }\end{array}$ \\
\hline $4 / \mathrm{M} / \mathrm{H}$ & $\begin{array}{l}\text { 1st: WCC, } 18 \text { (91\% lymphs); } \\
\text { 2nd: WCC, } 3 \text { (80\% lymphs; } \\
1 \text { wk after initial CSF) }\end{array}$ & $H S V-1^{a, b}$ & $\begin{array}{l}\text { NMDA-R Ab, d,f ANA } \\
(3.5)^{d, e}\end{array}$ & Negative (3.5) & Presented in status epilepticus & $\begin{array}{l}\text { Anti-NMDA-R } \\
\text { encephalitis, post-HSV- } \\
1 \text { encephalitis }\end{array}$ & $\begin{array}{l}\text { Some response to antivirals. No } \\
\text { improvement after IVMP and IVlg. } \\
\text { Remained nonambulatory and minimally } \\
\text { interactive }\end{array}$ \\
\hline $21 / M / H$ & WCC, 60 (90\% lymphs) & $\mathrm{EBV}^{\mathrm{a}}$ & NMDA-R Ab $(0)^{a, c}$ & Negative (0) & $\begin{array}{l}\text { Severe course of progressive decline } \\
\text { typical of NMDA-R encephalitis } \\
\text { requiring ICU admission }\end{array}$ & $\begin{array}{l}\text { Anti-NMDA-R } \\
\text { encephalitis }\end{array}$ & $\begin{array}{l}\text { Limited response to IVMP, PLEX, IVIg, } \\
\text { rituximab, and cyclophosphamide }\end{array}$ \\
\hline $57 / F / C$ & $\begin{array}{l}\text { 1st: WCC, } 59 \text { (78\% lymphs); } \\
\text { protein, } 46 ; 2 \text { 2nd: WCC, 2; } \\
\text { protein, } 74\end{array}$ & $H S V-1^{a, b}$ & UNA ${ }^{\mathrm{de} e \mathrm{e}}$ SMA (12) $)^{\mathrm{de} e}$ & Negative (16) & $\begin{array}{l}\text { Presented with encephalopathy, } \\
\text { diagnosed with HSE. Renal cell } \\
\text { carcinoma found }\end{array}$ & $\begin{array}{l}\text { Paraneoplastic } \\
\text { encephalitis }\end{array}$ & $\begin{array}{l}\text { Some response to antivirals and oral } \\
\text { prednisone but still had severe residual } \\
\text { amnestic disorder }\end{array}$ \\
\hline 65/M/NA & $\begin{array}{l}\text { 1st: WCC, 27; protein, 200; } \\
\text { 2nd: WCC, 10; 3rd: } \\
\text { WCC, 10; protein, } 54\end{array}$ & $\mathrm{EBV}^{\mathrm{a}, \mathrm{b}} \mathrm{HHV}-\mathrm{G}^{\mathrm{a}, \mathrm{g}}$ & UNA (12) $)^{d, e, g}$ & $\begin{array}{l}\text { Striational, AChRBi, } \\
\text { AChRMo, UNA (O) }\end{array}$ & $\begin{array}{l}\text { Progressive encephalopathy, } \\
\text { became minimally responsive over } 1 \mathrm{y} \text {. } \\
\text { No cancer }\end{array}$ & $\begin{array}{l}\text { Encephalitis of } \\
\text { unknown cause }\end{array}$ & $\begin{array}{l}\text { Minimal response to antivirals, steroids, } \\
\text { and IVlg }\end{array}$ \\
\hline 71/F/NA & WCC, 47 & $H S V-1^{a}$ & $\mathrm{GABA}_{\mathrm{B}}-\mathrm{R} A \mathrm{~b}(0)^{\mathrm{a}, \mathrm{c}}$ & $\begin{array}{l}\text { VGCC-N and } \\
\text { VGCC-P/Q }(0)^{h}\end{array}$ & $\begin{array}{l}\text { Progressive cognitive decline and } \\
\text { aphasia. Identified HSV-1 and GABA } \mathrm{B} \\
\text { CSF; small cell carcinoma of lung found }\end{array}$ & $\mathrm{GABA}_{\mathrm{B}}-\mathrm{R}$ encephalitis & Some improvement with IVlg \\
\hline
\end{tabular}

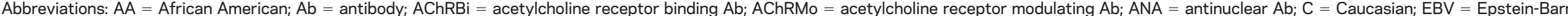

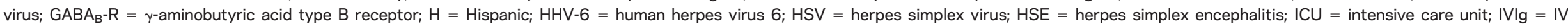

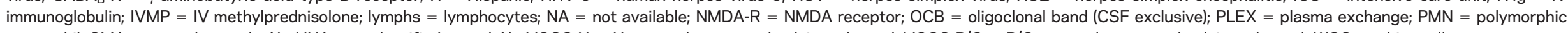

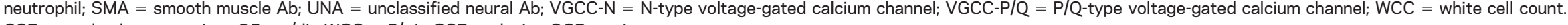

CSF normal values: protein, $\leq 35 \mathrm{mg} / \mathrm{dL} ; \mathrm{WCC}, \leq 5 / \mu \mathrm{L} ;$ CSF-exclusive OCBs, $<4$

${ }^{\text {a }}$ Detected in first CSF tested.

${ }^{b}$ Virus testing documented and negative in 2nd CSF tested.

${ }^{\mathrm{c}} \mathrm{Ab}$ detected by tissue-based immunofluorescence assay and cell-based assay.

${ }^{\mathrm{d}} \mathrm{Ab}$ detected in 2 nd CSF tested.

e Detected by tissue-based immunofluorescence assay.

${ }^{\mathrm{f}} \mathrm{Ab}$ detected by cell-based assay only.

${ }^{9}$ Detected in all CSF specimens tested.

${ }^{\mathrm{h}}$ Detected by immunoprecipitation assay. 
codetected in CSFs submitted for herpes and autoimmune encephalitis evaluation. The species of herpes viruses (HSV-1/2, VZV, EBV, HHV-6, and CMV) and antibodies detected (most commonly unclassified neural or nonneural IgGs) were diverse. For some patients in whom longitudinal clinical data and specimens were available (mostly anecdotal), clinical and CSF testing results indicated sequential clinical events (remitting viral encephalitis, followed by autoimmune encephalitis). Some patients had the now well-described parainfectious phenomenon of antiNMDA-R encephalitis after HSV-1 encephalitis. Consistent with previous reports, many (half) of those patients were children and neoplasms were not found. ${ }^{7-11}$ For others, testing results were also suggestive of sequential viral and parainfectious autoimmune disorders, although distinct clinical phases could not be discerned. In other patients, the clinical significance of the detected herpes viruses and antibodies was uncertain. Latent neurotropic virus may be reactivated or shed as a consequence of CNS inflammation, and autoimmune responses to disparate neural antigens during viral infection may occur.

The herpes virus PCR-positive cohort (group 1), which consisted of patients with CSFs submitted on a clinical basis for herpes virus testing, and evaluated on a research basis for autoantibodies, provided a snapshot of other parainfectious autoimmune phenomena arising during CNS herpes infection. Consistent with a previous report, uncharacterized neural antibodies were commonly detected in CSF. ${ }^{7}$ In addition, we also detected a high frequency of nonneural autoantibodies, either organ-specific (such as SMA and GPC antibody) or non-organ-specific (ANA). A similar profile of nonneural antibodies is frequently detected in patients with paraneoplastic autoimmunity. ${ }^{21}$ We did not have clinical data or sera available to determine whether the detected non-organspecific autoimmunity was attributable to coexisting systemic autoimmune disease or advanced age, rather than occurring in the context of CNS infection. ${ }^{22}$ Nonneural autoantibodies detected in CSF may also indicate nonspecific immune activation during infection, rather than heralding impending neural-specific autoimmunity. Repeat CSF data were limited to those patients who had CSF resubmitted on a clinical basis.

Our findings confirm that parainfectious autoimmunity may occur in the context of EBV and VZV, as reported previously. ${ }^{10,13,23}$ In 4 of 5 cases (from groups 1-3) where the clinical histories were known, patients with EBV-positive CSF also had NMDA-R antibodies detected. With this study, we additionally demonstrated AMPA-R autoimmunity post-HSV-1 encephalitis and neurally directed antibodies in the setting of HHV-6 infection. Together, these results demonstrate a spectrum of coexisting herpes viruses and antibodies extending beyond HSV-1 and NMDA-R antibodies.

The rate of resubmission of CSF (10\%) from group 1 is consistent with a sizable number of patients with herpes encephalitis having prolonged or complicated courses, prompting clinicians to re-evaluate. A recent prospective study of herpes simplex encephalitis cases found that $25 \%$ of patients had immunemediated relapsing neurologic sequelae. ${ }^{12}$ It was also found in the same study that adults who did not have hyperkinetic movements and altered consciousness often had delayed diagnoses when compared with children who had these symptoms. Those findings and our data suggest that postviral autoimmune encephalitis remains underrecognized in clinical practice, and that opportunities for neurologic improvement with immunotherapy may be missed. ${ }^{12}$

Our autoimmune encephalitis cohort (group 2) demonstrated herpes virus PCR positivity (HHV-6 and EBV) in 4 of 77 patients (5\%), although the timing of CSFs submission may have affected sensitivity. CSFs may have been submitted for antibody testing weeks to months after symptom onset, by which time herpes PCR testing might have proven negative.

The significance of herpes virus PCR positivity was uncertain in 3 of 4 patients with autoimmune encephalitis (group 2) and 4 of 10 incidental cases (group 3). Of those 7 patients, a paraneoplastic cause (rather than parainfectious) seemed most likely in 3. This uncertainty seemed particularly true for those patients in whom HHV-6 was detected, and was exemplified further by one control patient with cryptogenic intractable chronic focal epilepsy who was HHV-6-positive (and neural autoantibodynegative). Of 4 patients in groups 1,2 , or 3 who had HHV-6-positive CSF and histories known, one had HHV-6 viremia and likely CNS infection, one had encephalopathy of unknown cause, and 2 had malignancies (small cell carcinoma and $\mathrm{T}$ cell lymphoma) prompting consideration of a paraneoplastic rather than parainfectious encephalitis. Post hoc, we reviewed the available Mayo Clinic histories of 2 additional antibody-negative patients from group 1 with HHV-6 CSF positivity. In contrast to our antibodypositive patients, both were immunocompromised and had unambiguous clinical and radiologic features supportive of HHV-6 encephalitis. One had myelodysplastic syndrome and the other had diffuse systemic (excluding CNS) large B cell lymphoma.

It is possible that CSF herpes PCR positivity may occur in some patients because of shedding of latent neurotropic viral DNA in the course of paraneoplastic encephalitis. Reactivation of infection in that context cannot be excluded either (and we did not undertake confirmatory viral cultures from archived CSFs). ${ }^{24}$ 
PCR positivity for $\mathrm{HSV}-1, \mathrm{HHV}-6$, and EBV in CSF, occurring without additional evidence supporting CNS infection, has also been reported among immunosuppressed patients and those with neurodegenerative disorders or stroke. ${ }^{25,26}$

Although serum was not available for groups 1 and 2 , antibody data were available for both serum and CSF among our incidental cases. In 6 of those 10 cases, antibodies were detected in CSF alone, supporting the concept of a CNS-predominant immune response (antiviral and autoimmune). An animal model study of herpes simplex encephalitis, which did not include testing for neural autoantibodies, demonstrated a sustained inflammatory response after recovery from herpes infection. ${ }^{27}$ Ours and previous data support the possibility of autoimmunity contributing to this persistent CNS inflammation. ${ }^{7}$ Before the availability of antiviral therapy, corticosteroids (anti-inflammatory) had been reported to be beneficial for reducing edema in HSV encephalitis. ${ }^{28,29}$ Use of corticosteroids combined with antiviral therapy was associated with improved outcome in HSV encephalitis in a retrospective study, but controlled clinical trials are lacking in this area. ${ }^{30,31}$

Detection of a herpes virus (usually HSV-1) and diverse autoantibodies in the CSF may signify a parainfectious autoimmune response in many patients. That response may initially be nonneural but, in some cases, matures into an attack directed at specific neural receptors (such as NMDA-R), which may manifest as a relapsing biphasic illness. The frequent coexistence of autoimmune markers in patients with CNS herpes infection raises several mechanistic and therapeutic questions, which may be answered by animal model studies and clinical trials. ${ }^{32}$ Caution regarding the interpretation of herpes virus PCR, unclassified, and nonneural antibody results in CSF is advised where other clinical or supportive features of CNS infection or autoimmunity are absent.

\section{AUTHOR CONTRIBUTIONS}

J.L.: study design, data collection and analysis, and drafting and critical revision of manuscript. M.B.: data collection and analysis, and critical revision of manuscript. M.M.: data collection and critical revision of manuscript. C.K.: study concept and design, and critical revision of manuscript. A.M.: study concept and design, data analysis, and drafting and critical revision of manuscript.

\section{ACKNOWLEDGMENT}

The authors acknowledge Debby Svihel and Elise Bieri (Neuroimmunology Laboratory) and Cole Irish and Mark Espy (Virology Laboratory) for excellent technical support.

\section{STUDY FUNDING}

No targeted funding.

\section{DISCLOSURE}

J. Linnoila received research support from NIH. M. Binnicker and M. Majed report no disclosures. C.J. Klein received research support from the NINDS. A. McKeon received research support from MedImmune. Go to Neurology.org/nn for full disclosure forms.

Received March 8, 2016. Accepted in final form April 17, 2016.

\section{REFERENCES}

1. Linnoila JJ, Rosenfeld MR, Dalmau J. Neuronal surface antibody-mediated autoimmune encephalitis. Semin Neurol 2014;34:458-466.

2. Albert ML, Darnell JC, Bender A, Francisco LM, Bhardwaj N, Darnell RB. Tumor-specific killer cells in paraneoplastic cerebellar degeneration. Nat Med 1998;4: 1321-1324.

3. Yuki N, Susuki K, Koga M, et al. Carbohydrate mimicry between human ganglioside GM1 and Campylobacter jejuni lipooligosaccharide causes Guillain-Barré syndrome. Proc Natl Acad Sci USA 2004;101:11404-11409.

4. Dalmau J, Tuzun E, Wu HY, et al. Paraneoplastic anti-Nmethyl-D-aspartate receptor encephalitis associated with ovarian teratoma. Ann Neurol 2007;61:25-36.

5. Titulaer MJ, McCracken L, Gabilondo I, et al. Treatment and prognostic factors for long-term outcome in patients with anti-NMDA receptor encephalitis: an observational cohort study. Lancet Neurol 2013;12:157-165.

6. Pruss H, Finke C, Holtje M, et al. N-methyl-D-aspartate receptor antibodies in herpes simplex encephalitis. Ann Neurol 2012;72:902-911.

7. Armangue T, Leypoldt F, Malaga I, et al. Herpes simplex virus encephalitis is a trigger of brain autoimmunity. Ann Neurol 2014;75:317-323.

8. Armangue T, Titulaer MJ, Malaga I, et al. Pediatric antiN-methyl-D-aspartate receptor encephalitis: clinical analysis and novel findings in a series of 20 patients. J Pediatr 2013;162:850-856.e2.

9. Hacohen Y, Deiva K, Pettingill P, et al. N-methyl-D-aspartate receptor antibodies in post-herpes simplex virus encephalitis neurological relapse. Mov Disord 2014;29:90-96.

10. Leypoldt F, Titulaer MJ, Aguilar E, et al. Herpes simplex virus-1 encephalitis can trigger anti-NMDA receptor encephalitis: case report. Neurology 2013;81:1637-1639.

11. Armangue T, Moris G, Cantarin-Extremera V, et al. Autoimmune post-herpes simplex encephalitis of adults and teenagers. Neurology 2015;85:1736-1743.

12. De Tiege X, Rozenberg F, Des Portes V, et al. Herpes simplex encephalitis relapses in children: differentiation of two neurologic entities. Neurology 2003;61:241-243.

13. Schabitz WR, Rogalewski A, Hagemeister C, Bien CG. VZV brainstem encephalitis triggers NMDA receptor immunoreaction. Neurology 2014;83:2309-2311.

14. Lennon VA. Anti-Purkinje cell cytoplasmic and neuronal nuclear antibodies aid diagnosis of paraneoplastic autoimmune neurological disorders. J Neurol Neurosurg Psychiatry 1989;52:1438-1439.

15. Pittock SJ, Yoshikawa H, Ahlskog JE, et al. Glutamic acid decarboxylase autoimmunity with brainstem, extrapyramidal, and spinal cord dysfunction. Mayo Clin Proc 2006; 81:1207-1214.

16. O’Toole O, Lennon VA, Ahlskog JE, et al. Autoimmune chorea in adults. Neurology 2013;80:1133-1144.

17. Espy MJ, Uhl JR, Mitchell PS, et al. Diagnosis of herpes simplex virus infections in the clinical laboratory by LightCycler PCR. J Clin Microbiol 2000;38:795-799.

18. Espy MJ, Teo R, Ross TK, et al. Diagnosis of varicellazoster virus infections in the clinical laboratory by LightCycler PCR. J Clin Microbiol 2000;38:3187-3189. 
19. Khare R, Espy MJ, Mandrekar JN, Binnicker MJ. Comparison of a transplant multiplex viral panel on the ICEPlex system with real-time PCR for detection of cytomegalovirus, Epstein-Barr virus, and BK virus in clinical specimens. J Clin Microbiol 2014;52:1711-1713.

20. Binnicker MJ, Espy ME. Comparison of six real-time PCR assays for qualitative detection of cytomegalovirus in clinical specimens. J Clin Microbiol 2013;51:3749-3752.

21. Lennon VA, Lambert EH, Whittingham S, Fairbanks V. Autoimmunity in the Lambert-Eaton myasthenic syndrome. Muscle Nerve 1982;5:S21-S25.

22. Selmi C, Ceribelli A, Generali E, et al. Serum antinuclear and extractable nuclear antigen antibody prevalence and associated morbidity and mortality in the general population over 15 years. Autoimmun Rev 2016;15:162-166.

23. Xu CL, Liu L, Zhao WQ, et al. Anti-N-methyl-D-aspartate receptor encephalitis with serum anti-thyroid antibodies and IgM antibodies against Epstein-Barr virus viral capsid antigen: a case report and one year follow-up. BMC Neurol 2011;1:149.

24. Tyler KL. Herpes simplex virus infections of the central nervous system: encephalitis and meningitis, including Mollaret's. Herpes 2004;11(suppl 2):57A-64A.

25. Plentz A, Jilg W, Kochanowski B, Ibach B, Knoll A. Detection of herpesvirus DNA in cerebrospinal fluid and correlation with clinical symptoms. Infection 2008;36:158-162.
26. Kleines M, Scheithauer S, Schiefer J, Hausler M. Clinical application of viral cerebrospinal fluid PCR testing for diagnosis of central nervous system disorders: a retrospective 11-year experience. Diagn Microbiol Infect Dis 2014; 80:207-215.

27. Sellner J, Dvorak F, Zhou Y, et al. Acute and long-term alteration of chemokine mRNA expression after anti-viral and anti-inflammatory treatment in herpes simplex virus encephalitis. Neurosci Lett 2005;374:197-202.

28. Upton AR, Barwick DD, Foster JB. Dexamethasone treatment in herpes-simplex encephalitis. Lancet 1971;1: 290-291.

29. Habel AH, Brown JK. Dexamethasone in herpes-simplex encephalitis. Lancet 1972;1:695.

30. Kamei S, Sekizawa T, Shiota H, et al. Evaluation of combination therapy using aciclovir and corticosteroid in adult patients with herpes simplex virus encephalitis. J Neurol Neurosurg Psychiatry 2005;76:1544-1549.

31. Kennedy PG, Steiner I. Recent issues in herpes simplex encephalitis. J Neurovirol 2013;19:346-350.

32. Martinez-Torres F, Menon S, Pritsch M, et al. Protocol for German Trial of Acyclovir and Corticosteroids in HerpesSimplex-Virus-Encephalitis (GACHE): a multicenter, multinational, randomized, double-blind, placebo-controlled German, Austrian and Dutch trial [ISRCTN45122933]. BMC Neurol 2008;8:40. 


\section{Neurology \\ Neuroimmunology \& Neuroinflammation}

CSF herpes virus and autoantibody profiles in the evaluation of encephalitis

Jenny J. Linnoila, Matthew J. Binnicker, Masoud Majed, et al.

Neurol Neuroimmunol Neuroinflamm 2016;3;

DOI 10.1212/NXI.0000000000000245

This information is current as of June 1, 2016

\section{Updated Information \& Services}

References

Citations

Subspecialty Collections

Permissions \& Licensing

Reprints including high resolution figures, can be found at: http://nn.neurology.org/content/3/4/e245.full.html

This article cites 32 articles, 7 of which you can access for free at: http://nn.neurology.org/content/3/4/e245.full.html\#\#ref-list-1

This article has been cited by 1 HighWire-hosted articles: http://nn.neurology.org/content/3/4/e245.full.html\#\#otherarticles

This article, along with others on similar topics, appears in the following collection(s):

All Infections

http://nn.neurology.org//cgi/collection/all_infections

Autoimmune diseases

http://nn.neurology.org//cgi/collection/autoimmune_diseases

Encephalitis

http://nn.neurology.org//cgi/collection/encephalitis

Paraneoplastic syndrome

http://nn.neurology.org//cgi/collection/paraneoplastic_syndrome

Information about reproducing this article in parts (figures,tables) or in its entirety can be found online at:

http://nn.neurology.org/misc/about.xhtml\#permissions

Information about ordering reprints can be found online:

http://nn.neurology.org/misc/addir.xhtml\#reprintsus

Neurol Neuroimmunol Neuroinflamm is an official journal of the American Academy of Neurology.

Published since April 2014, it is an open-access, online-only, continuous publication journal. Copyright $(\odot$ 2016 American Academy of Neurology. All rights reserved. Online ISSN: 2332-7812.

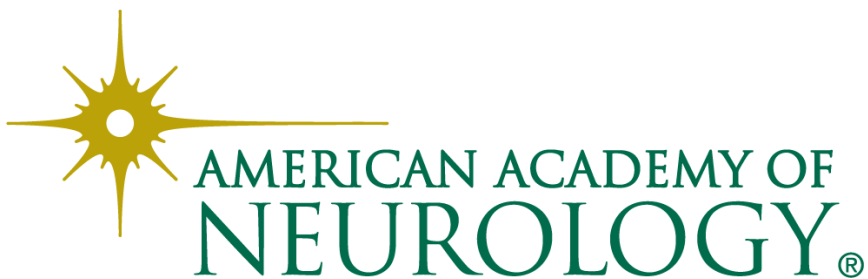

